\title{
KEANEKARAGAMAN JENIS IKAN AIR TAWAR DI SUNGAI DONG SANDAR DAN SUNGAI REMPANGI DI KECAMATAN SUNGAI LAUR KABUPATEN KETAPANG
}

\author{
(Freshwater Fish Species Diversity In Dong Sandar And Rempangi Rivers Sungai Laur \\ Subdistrict, Ketapang District)
}

\author{
Ongki Saputra, Muhamad Sofwan Anwari, Ratna Herawatiningsih \\ Fakultas Kehutanan Universitas Tanjungpura Pontianak, Jl. Daya Nasional Pontianak 78124 \\ Email : saputra.ongki0309@gmail.com
}

\begin{abstract}
Deforestation will affect changes in the condition of the waters of the protected and secondary forest watersheds that can affect in it biota. Fish have limited ability to choose areas that are safe for their lives, especially the environment that is very supportive for the availability of food sources. The fish population in the Dong Sandar River and Rempangi as well as the diversity of fish species in both rivers is unknown. The problem of this research is how the diversity of fish species in the Dong Sandar River and Rempangi River, Sungai Laur District, Ketapang. Research on the diversity of freshwater fish species in the Dong River between the protection of protected forests and the Rempangi River in the secondary forest of Sungai Laur Subdistrict, Ketapang District, West Kalimantan consisting of 20 stations each of which there are 10 observation stations conducted on May 1 - 21, 2018. The selection of observation stations is selected (purposive sampling) which is based on consideration of the conditions and conditions of the aquatic environment. The results of the research were 884 individuals from 50 species of 18 families with the use of scattered, pukat, seluak, bubu, temilar, sauk, and ambe exploration tools. The most types of fish obtained on the Dong Sandar River and Rempangi River consist of the Cyprinidae family (20 species), Bagridae family (7 species), Siluridae family (4 species). The diversity of fish species in the Dong Sandar River and Rempangi River in Ketapang Regency is relatively moderate $\left(H^{\prime}<3\right)$ with a diversity index $\left(H^{\prime}\right)$ of 2.94 , if $H^{\prime}<1$ means low diversity, if 1 $<H^{\prime}<3$ means moderate diversity and if $H^{\prime}>3$ means high species diversity. The dominant index (C) on the Dong Sandar River is 0.09 while in the Rempangi River 0.11, the range of dominant index values is $0-1$ if the value $C=0$ means that there are no types of fish dominating and if $C$ $=1$ means there are other types of fish dominating. The highest evenness index $(E)$ is found in the Rempangi River of 0.77 and in the Dong Sandar River 0.76, it can be seen the range of evenness of species index 0-1 if the value $E=0$ means low type evenness, and if the value $E=1$ means evenness is relatively evenly. The species richness index $(R)$ of the Dong Sandar River has abundant types of fish with a value of 7.26 while in the Rempangi River only 4.40. Evenness on both rivers is $57.53 \%$.
\end{abstract}

Keyword: Diversity, Dong Sandar River, Fish, Rempangi River

\section{PENDAHULUAN}

Indonesia merupakan negara kepulauan yang terdiri atas sekitar 17.508 pulau dengan panjang garis pantai 81.000 $\mathrm{Km}$. Total luas wilayah Indonesia, sebagian besar adalah perairan dengan perbandingan daratan dan perairan sebesar 1:3. Pulau Kalimantan, khususnya Kalimantan Barat telah dikenal dengan keanekaragaman jenis ikan air tawar yang tinggi. Kalimantan memiliki potensi perairan yang sangat besar baik perairan darat maupun perairan 
laut. Luas perairan darat Kalimantan Barat adalah sekitar 2.000.000 hektar yang terdiri atas danau rawa dan sungai (Utomo $d k k$., 1999). Perairan yang demikian luas terdapat kekayaan sumber daya alam hayati maupun sumber daya alam non hayati.

Sumber daya alam hayati yang lainnya, keanekaragaman jenis ikan yang termasuk keanekaragaman genetik didalamnya harus di pelihara karena merupakan proses evolusi dan pemuliaan dimasa mendatang. Spesies air tawar sebanyak 13.000 yang hidup di danau maupun di sungai yang memiliki cakupanya hanya $1 \%$ di permukaan bumi ini, sedangkan yang hidup di air laut memiliki 16.000 spesies yang merupakan $70 \%$ bagian dari permukaan bumi (Leveque dalam Mahendra $d k k$., 2018). Sampai saat ini jumlah ikan di dunia berdasarkan identifikasi sebanyak 24.618 jenis, dan $40 \%$ diantaranya ikan air tawar (Nelson dalam Haryono. 2009).

Menurut Adiesoemarto dan Rivai (1992) ada sekitar 8.500 spesies ikan yang terdapat pada perairan Indonesia, diperkirakan jumlah jenis ikan tersebut akan masih bertambah dengan ditemukannya jenis-jenis terbaru. Indonesia menempati rangking kedua di dunia setelah Brazil, dan di Asia Indonesia menempati rangking pertama dengan jumlah jenis ikan air tawar terbanyak (Budiman dkk., 2002). Kalimantan memiliki lebih kurang 350 spesies ikan air tawar, 135 merupakan endemik di pulau ini. Habitat yang banyak dihuni ikan air tawar ialah seperti sungai, danau, dan rawarawa (Kottelat $d k k$. 1993).
Kecamatan Sungai Laur memiliki hutan lindung maupun hutan sekunder yang memiliki anak-anak sungai, salah satunya berada di Desa Teluk Bayur dan Desa Sempurna. Hutan lindung berada pada kawasan Desa Sempurna yang memiliki sungai bernama Dong Sandar, sedangkan hutan sekunder berada pada kawasan Desa Teluk Bayur yang memiliki sungai bernama Rempangi. Kondisi Sungai Dong Sandar saat ini memiliki potensi untuk mendukung kehidupan satwa di air, karena hutan di sekitarnya masih terjaga kelestariannya. Kondisi air yang jernih dan terjaga dari sampah membuat sungai ini banyak masyarakat yang menangkap ikan menggunakan alat tradisional sebagai sumber pakan sehari-hari. Sungai Rempangi memiliki hutan yang sudah tidak alami, apalagi di hulu sungai tersebut banyak perkebunan kelapa sawit yang menyebabkan air sungai menjadi keruh dan terkena bahan kimia dari sisa-sisa pupuk. Penelitian ini bertujuan untuk mengetahui keanekaragaman jenis ikan air tawar pada kawasan hutan lindung (Sungai Dong Sandar) dan kawasan hutan sekunder (Sungai Rempangi) di Kecamatan Sungai Laur Kabupaten Ketapang.

\section{BAHAN DAN METODE}

Penelitian dilaksanakan di Sungai Dong Sandar yang terdapat di hutan lindung Desa Sempurna dan Sungai Rempangi di hutan sekunder Desa Teluk Bayur Kecamatan Sungai Laur Kabupaten Ketapang. Penelitian ini dilakukan selama 3 (tiga) minggu efektif di lapangan mulai tanggal 01 sampai dengan 21 Mei 2018.

Peralatan yang digunakan dalam penelitian ini adalah Peta Lokasi Penelitian 
Skala 1 : 170.000, Umpan ikan (buah sawit), Jala Tebar (mata jaring $2 \mathrm{~cm}$ ), Pukat (mata jaring $2 \mathrm{~cm}, 3 \mathrm{~cm}$, dan $4 \mathrm{~cm}$ ), Seluak (dari botol minuman), Bubu (dari bambu dan rotan), Temilar (dari rotan), Sauk (mata jaring $1 \mathrm{~cm}$ ), Ambe (dari bambu dan pukat dengan mata jaring $1 \mathrm{~cm}$ ), Sampan, Penggaris, Timbangan, GPS (Global Positioning System), Kamera, Meteran, Thally sheet, Buku identifikasi ikan (Kottelat dkk., 1993), dan Alat tulis menulis.
Penentuan titik sampling dengan Purposive Sampling dan diikuti secara Sistematik (Effendie, 1979) berdasarkan pada kondisi lingkungan. Peletakan titik dilaksanakan di Sungai Dong Sandar di hutan lindung dan Sungai Rempangi di hutan sekunder. Masing-masing lokasi di buat 10 (sepuluh) stasiun atau titik dengan jarak 50 meter dan interval per jarak antar stasiun sepanjang 100 meter. Setiap stasiun dilakukan pengambilan sampel hanya 1 (satu) kali pengulangan.

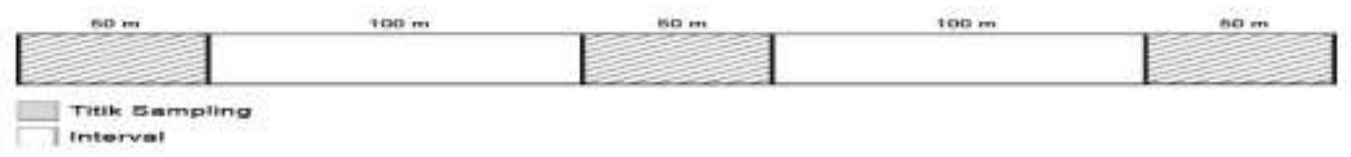

\section{Gambar 1. Pengambilan Titik Sampling (Sampling Point Collection)}

Pengambilan sampel ikan dilakukan dengan metode hasil tangkap per unit usaha (Rachmatika dan Haryono 1996) yaitu dengan menggunakan alat tangkap jala dengan 10 kali tebaran setiap stasiun, perlakuan dengan 1 utas pukat (mata jaring $2 \mathrm{~cm}, 3 \mathrm{~cm}$, dan $4 \mathrm{~cm}$ ) setiap stasiun, perlakuan dengan ambe sebanyak 4 kali pengulangan setiap stasiun, perlakuan dengan 3 buah seluak satu ditengah dan dua di tepian sungai setiap stasiun, perlakuan dengan 1 buah bubu di tepian sungai setiap stasiun dan 1 buah temilar di pasang tepian sungai setiap stasiun. Sebelum menebar jala terlebih dahulu menghamburkan umpan supaya menghasilkan jumlah tangkap yang banyak. Pemasangan Seluak, bubu, dan temilar akan dilakukan sehari sebelum pengambilan sampel di stasiun. Sampel ikan yang tertangkap pada setiap lokasi dicatat jenis dan jumlahnya, diukur panjang total dan panjang standar, ditimbang beratnya, setiap jenis ikan dibuat dokumentasinya, identifikasi dan determinasi mengacu kepada buku identifikasi (Kottelat $d k k$., 1993).

\section{Analisis Data}

Analisis data digunakan rumus menurut Ferianita (2007)

Indeks Dominasi (Indeks of Dominance)

$\mathrm{C}=\Sigma(\mathrm{ni} / \mathrm{N})^{2}$

Dimana :

$\mathrm{ni}=$ Jumlah individu suatu jenis

$\mathrm{N}=$ Jumlah individu seluruh jenis

Nilai indeks berkisar antara 0-1

$\mathrm{C}=0$, berarti tidak terdapat jenis yang mendominasi jenis lainya

$\mathrm{C}=1$, berarti terdapat jenis yang mendominasi jenis lainnya

Indeks Keanekaragaman Jenis (Indeks of Diversity)

$\mathrm{H}^{\prime}=\sum_{i=1}^{s}\left(n_{i} / N\right) \operatorname{In}\left(n_{i} / N\right)$ 
Dimana:

$\mathrm{H}^{\prime}$ = indeks keanekaragaman

$\mathrm{S}=$ jumlah jenis ikan

$\mathrm{N}=$ jumlah individu ikan

$\mathrm{Ni}=$ jumlah individu ikan tiap jenis ke-i

Kriteria:

$\mathrm{H}<1=$ keanekaragaman jenis rendah

$1<\mathrm{H}^{\prime}<3=$ keanekaragaman jenis sedang

$\mathrm{H}^{\prime}>3=$ keanekaragaman jenis tinggi

Indeks Kemerataan Jenis (Species Evennes)

$\mathrm{E}=\frac{H^{\prime}}{\operatorname{In}(S)}$

Dimana:

$H^{\prime}$ = indeks keanekaragaman Shannon -

Wienner

$\mathrm{S}=$ jumlah jenis

Nilai indeks berkisar antara 0-1

$\mathrm{E}=0$, berarti kemerataan jenis rendah

$\mathrm{E}=1$, berarti kemerataan jenis relative merata/sama

Indeks Kekayaan Jenis (Species Richness)

$\mathrm{R}=\frac{S-1}{\operatorname{In}(N)}$

Dimana:

$\mathrm{N}=$ jumlah seluruh individu

$\mathrm{S}=$ jumlah jenis

Indeks Kesamaan Jenis (Indeks of

Similarity) Sorensen / (IS)

IS $=\frac{2 C}{A+B} \times 100 \%$

Dimana:

$\mathrm{A}=$ jumlah jenis di daerah 1

$\mathrm{B}=$ jumlah jenis di daerah 2

$\mathrm{C}=$ jumlah jenis yang sama di kedua daerah

Indeks Biologi (IB)

Penentuan IB dilakukan dengan cara memberikan nilai menurut besarnya jumlah individu satu jenis ikan yang tertangkap. Jumlah individu satu jenis ikan terbesar atau terbanyak jumlah individunya diberi nilai tertinggi 10 , urutan selanjutnya diberi nilai 9, demikian sampai seterusnya sampai dengan nilai yang terkecil yaitu 1. Nilai setiap jenis per sampel dijumlahkan sehingga memperoleh nilai total dari keseluruhan pengambilan sampel.

Perhitungan Biometri

Perhitungan biometri adalah studi tentang metode otomatis untuk mengenali mahluk hidup berdasarkan satu atau lebih bagian tubuh atau kelakuan dari mahluk hidup itu sendiri yang memiliki keunikan.

Hubungan panjang - berat dianalisa dengan rumus regresi linier

$\log \mathrm{a}=$

$\frac{\sum \log W \times \sum(\log L)^{2}-\sum \log L x \sum(\log L x \log W)}{N \times \sum X^{2}-\left(\sum X\right)^{2}}$

$\mathrm{b}=\frac{\sum \log W-(N x \log a)}{\sum \log L}$

Hubungan panjang - tinggi dihitung dengan rumus regresi linier

$\mathrm{a}=\frac{\sum \log W x \sum X^{2}-\sum \log X x \sum X Y}{N \times \sum X^{2}-\left(\sum X\right)^{2}}$

$\mathrm{b}=\frac{\sum Y-(N X A)}{\sum X}$

Dimana:

$\mathrm{W}=$ Berat Ikan

$\mathrm{X}=$ Tinggi Ikan

$\mathrm{L}, \mathrm{Y} \quad=$ Panjang Ikan

$\mathrm{a}$ dan $\mathrm{b}=$ Konstanta

$a$ dan $b=$ bilangan yang harus dicari

Jika nilai $b=3$ disebut isometrik, dan jika $b$ $>3$ disebut allometrik

\section{HASIL DAN PEMBAHASAN}

Jumlah ikan air tawar yang ditemukan pada kawasan Sungai Dong Sandar dan Sungai Rempangi sebanyak 884 individu, yang tergolong dalam 50 jenis ikan dalam 18 famili. Sungai Dong Sandar terdapat 428 individu, yang tergolong dalam 45 jenis ikan dan Sungai Rempangi terdapat 456 individu, yang tergolong dalam 28 jenis. Jenis ikan yang ditemukan di Sungai 
Dong Sandar dan Sungai Rempangi

disajikan pada tabel 1 dan tabel 2.

Tabel 1. Daftar Jenis Ikan Air Tawar yang ditemukan di Sungai Dong Sandar (Liss Of Types Freshwater Fish Found On The Dong Sandar River)

\begin{tabular}{|c|c|c|c|}
\hline No & Family & Nama Ikan (Ilmiah) & Nama Ikan (daerah) \\
\hline 1 & Ailiidae & Ledies hexanema & Reriu \\
\hline 2 & Anabantidae & Anabas testudineus & Kepuyu \\
\hline 3 & Bagridae & Mystus nemurus & Baong \\
\hline 4 & Bagridae & Mystus micracanthus & Baong Banir \\
\hline 5 & Bagridae & Hemibagrus sp & Baong Bure \\
\hline 6 & Bagridae & Mystus wcykii & Baong Layor \\
\hline 7 & Bagridae & Leiocassis sp & Petik Kantang \\
\hline 8 & Bagridae & Bagrichthys sp & Petik Menggerot \\
\hline 9 & Bagridae & Mystus nigriceps & Petik Mantong \\
\hline 10 & Channidae & Channa gachua & Ruan Delak \\
\hline 11 & Cobitidae & Botia macracantha & Belang Ulin \\
\hline 12 & Cobitidae & Botia hymenophysa & Diot \\
\hline 13 & Cobitidae & Botia reversa & Diot Curing \\
\hline 14 & Cynoglossidae & Cynoglossus waandersii & Ikan Sebelah \\
\hline 15 & Cyprinidae & Hampala macrolepidota & Adongan \\
\hline 16 & Cyprinidae & Oxygaster anomalura & Lelansi \\
\hline 17 & Cyprinidae & Cyclocheilichthys apogon & Emperas \\
\hline 18 & Cyprinidae & Labiobarbus festivus & Bantak Merah \\
\hline 19 & Cyprinidae & Barbichthys laevis & Kungkum \\
\hline 20 & Cyprinidae & Rasbora caudimaculata & Seluang Kenekor \\
\hline 21 & Cyprinidae & Chela Maasi & Main Angin \\
\hline 22 & Cyprinidae & Labiobarbus lineatus & Ikan Pasir \\
\hline 23 & Cyprinidae & Barbodes schawanenfeldii & Tengadak \\
\hline 24 & Cyprinidae & Rasbora cephalotaenia & Seluang Maram \\
\hline 25 & Cyprinidae & Rasbora tawarensis & Seluang Beras \\
\hline 26 & Cyprinidae & Osteochilus kappeni & Kebali \\
\hline 27 & Cyprinidae & Luciosoma trinema & Kelenjuar \\
\hline 28 & Cyprinidae & Anematichthys armatus & Buing \\
\hline 29 & Cyprinidae & Labiobarbus leptocheilus & Manso \\
\hline 30 & Cyprinidae & Osteochilus waandersii & Bantak Batang \\
\hline 31 & Cyprinidae & Barbodes sp. & Paro \\
\hline 32 & Cyprinidae & Pustinus anchispora & Simpe Kulak \\
\hline 33 & Helastomatodae & Helostoma temminckii & Biawan \\
\hline 34 & Hemiramphidae & Strongylura sp. & Pajag \\
\hline 35 & Luciociphalidae & Locephalus pulcher & Kejunju \\
\hline 36 & Mastacembelidae & Macrognathus aculeatus & Kempetar \\
\hline 37 & Mastacembelidae & Mastacembelus erythrotaenia & Tilan \\
\hline 38 & Osphronimidae & Osphronemus goramy & Kaloi \\
\hline 39 & Pristolepididae & Pristolepis grootii & Patong \\
\hline 40 & Siluridae & Kryptopterus lais & Lais \\
\hline 41 & Siluridae & Ompok hypophthalmus & Lais Hitam \\
\hline 42 & Siluridae & Kryptopterus palembangensis & Lais Tunggul \\
\hline 43 & Siluridae & Kryptopterus limpok & Lais Bulu \\
\hline 44 & Sisoridae & Bagarius yarrelli & Baong Dekat \\
\hline 45 & Tetraodontidae & Dichotomyctere nigroviridis & Buntal Pinang \\
\hline
\end{tabular}

Sungai Dong Sandar merupakan anakan sungai dari Sungai Laur, tetapi
Sungai Dong Sandar adalah sungai utama di kawasan sub DAS Hutan 
Lindung. Sepanjang Sungai Dong Sandar, jenis ikan air tawar yang tertangkap sebanyak 45 jenis yang didominasi oleh famili Cyprinidae (18 jenis). Tingginya keanekaragaman jenis di perairan Sungai Dong Sandar disebabkan beberapa faktor yaitu adanya variasi di dalam habitat Sungai Dong Sandar, terdapat beberapa jenis pakan yang melimpah, dan berhubungan langsung dengan kawasan hutan lindung. Hal ini menunjukan kedua kawasan hutan tersebut sangat berpengaruh

Tabel 2. Daftar Jenis Ikan Air Tawar yang ditemukan di Sungai Rempangi (Liss Of Types Freshwater Fish Found On The Rempangi River)

\begin{tabular}{clll}
\hline No & \multicolumn{1}{c}{ Famili } & \multicolumn{1}{c}{ Nama Ikan (Ilmiah) } & Nama Ikan (daerah) \\
\hline 1 & Bagridae & Bagrichthys sp & Petik Menggerot \\
2 & Bagridae & Hemibagrus sp & Baong Bure \\
3 & Bagridae & Mystus micracanthus & Baong Banir \\
4 & Bagridae & Mystus nemurus & Baong \\
5 & Bagridae & Mystus nigriceps & Petik Mantong \\
6 & Bagridae & Mystus wcykii & Baong Layor \\
7 & Belontidae & Tichogaster leerii & Sepat Siam \\
8 & Belontidae & Trychogaster trichopterus & Sepat \\
9 & Cyprinidae & Anematichthys armatus & Buing \\
10 & Cyprinidae & Barbichthys laevis & Kungkum \\
11 & Cyprinidae & Barbodes sp. & Paro \\
12 & Cyprinidae & Barbodes schawanenfeldii & Tengadak \\
13 & Cyprinidae & Chela Maasi & Main Angin \\
14 & Cyprinidae & Cyclocheilichthys apogon & Emperas \\
15 & Cyprinidae & Hampala macrolepidota & Adongan \\
16 & Cyprinidae & Labiobarbus leptocheilus & Manso \\
17 & Cyprinidae & Labiobarbus lineatus & Ikan Pasir \\
18 & Cyprinidae & Osteochilus kappeni & Kebali \\
19 & Cyprinidae & Oxygaster anomalura & Lelansi \\
20 & Cyprinidae & Pustinus anchispora & Simpe Kulak \\
21 & Cyprinidae & Pustinus Binotatus & Bebengkah \\
22 & Cyprinidae & Puntinus oligolepis & Tebalang \\
23 & Cyprinidae & Rasbora tawarensis & Seluang Beras \\
24 & Helastonatodae & Helostoma temminckii & Biawan \\
25 & Pristoleppididae & Pomacentrus taeniometopon & Kekepar \\
26 & Pomancentridae & Pristolepis grootii & Patong \\
27 & Siluridae & Kryptopterus palembangensis & Lais Tunggul \\
28 & Siluridae & Kryptopterus lais & Lais \\
\hline & & &
\end{tabular}

terhadap jenis ikan di Sungai Dong Sandar dan Sungai Rempangi.

Berdasarkan informasi yang didapat dari nelayan dan masyarakat, terdapat jenis ikan yang bersifat musiman (terdapat pada bulan-bulan tertentu) sehingga ikan ini tidak bisa ditangkap. Musim hujan banyak ikan yang mencari pakan keluar dari sarangnya (lubuk) sehingga susah untuk mendapatkannya, ikan akan menuju rawa-rawa atau pergi ke anakan sungai untuk mencari makan. 
Jumlah jenis ikan di Sungai Rempangi yang tertangkap adalah sebanyak 28 jenis yang didominasi oleh famili Cyprinidae (13 jenis). Menurut Roberts (1989) dan Kotelat $d k k .$, (1993), Cyprinidae merupakan ikan air tawar yang terbesar populasinya untuk sebagian besar sungai di Borneo dan hampir disetiap tempat di dunia.

Ikan air tawar di kawasan Sungai Dong Sandar dan Sungai Rempangi yang sering ditemukan adalah family dari Cyprinidae. Family Cyprinidae merupakan jenis ikan yang paling dominan yang bisa ditemukan disemua titik stasiun di Sungai Dong Sandar maupun Sungai Rempangi. Kelimpahan dari family Cyprinidae kemungkinan besar disebabkan karena tipe habitat pinggiran sungainya merupakan hutan yang masih alami dan lahan perkebunan kelapa sawit. Family Cyprinidae merupakan ikan yang gemar memakan lumut yang tersedia didalam air dari akar-akar pepohonan maupun buah kelapa sawit yang jatuh ke sungai.

Spesies ikan yang mendominasi di Sungai Dong Sandar adalah ikan Emperas (Cyclocheilichthys apogon) terdapat 103 individu dan di Sungai Rempangi ikan yang mendominasi adalah ikan Patong (Pristolepis grootii). Ikan tersebut merupakan ikan yang setiap tahunnya ditangkap oleh masyarakat untuk di konsumsi, walaupun ditangkap terus menerus tetapi ikan ini tidak pernah habis dikarenakan tingkat reproduksinya selalu tinggi. Sjafei $d k k$, (1993) menyebutkan bahwa keberhasilan reproduksi suatu individu ikan dipengaruhi oleh tingkat keberhasilan mendapatkan makanan atau energi untuk menghasilkan produk kelamin.

Sungai Dong Sandar memiliki jumlah 45 spesies dan Sungai Rempangi hanya berjumlah 28 spesies, tetapi dibandingkan dengan jumlah individunya Sungai Rempangi lebih banyak yang tertangkap karena dipengaruhi oleh lingkungan. Penelitian di Sungai Dong Sandar keadaan lingkungan di sekitar tidak memungkinkan karena banjir, ikan-ikan mencari makan memasuki daratan yang terendam oleh air. Ikan yang memasuki daratan yang terendam oleh banjir inilah salah satu penyebar biji tumbuhan pada hutan. Penelitian di Sungai Rempangi saat itu air tidak meluap ke daratan itu mempermudah penangkapan ikan yang menghasilkan jumlah tangkap individu melimpah, akan tetapi memang jumlah spesies pada Sungai Rempangi sedikit dikarenakan pada sungai ini lingkungannya sudah tercemar, penangkapan ikan yang menggunakan racun maupun tuba akar, menggunakan alat sentrum, zat kimia dari sisa pupuk perkebunan, inilah penyebab menurunnya jumlah spesies pada sungai tersebut. 
Tabel 3.Indeks Dominan, Indeks Keanekaragaman Jenis, Indeks Kemerataan Jenis, Indeks Kekayaan Jenis Ikan Air Tawar Sungai Dong Sandar dan Sungai Rempangi (Doninand Index, Species Diversity Index, Evenness Index Type, Species Richness Index Frenshwater Fish Dong Sandar and Rempangi River)

\begin{tabular}{lcc}
\hline \multicolumn{1}{c}{ Indeks } & Sungai Dong Sandar & Sungai Rempangi \\
\hline Dominan (C') & 0.096733 & 0.115886 \\
Keanekaragaman Jenis (H') & 2.897791 & 2.566213 \\
Kemerataan Jenis (E) & 0.761242 & 0.770124 \\
Kekayaan Jenis (R) & 7.261776 & 4.409969 \\
Kesamaan Jenis (IS) & $57.53 \%$ & $57.53 \%$ \\
\hline
\end{tabular}

Berdasarkan hasil perhitungan indeks dominansi jenis ikan air tawar, diketahui bahwa pada setiap perairan memiliki dominansi yang berbeda. Nilai indeks dominansi tertinggi terdapat pada Sungai Rempangi dengan nilai sebesar 0.115886 karena pada sungai ini terdapat ikan yang hidupnya secara mengelompok dan jenis ikan yang terdapat merupakan ikan yang memakan pakan seperti buah sawit yang banyak melimpah pada sungai tersebeut. Indeks dominansi Sungai Dong Sandar sebesar 0.096733 yang memiliki nilai indeks dominansi terendah dibandingkan dengan Sungai Rempangi karena pada sungai ini terdapat jumlah jenis yang melimpah tetapi jenis individu yang didapat hanya sedikit. Kisaran nilai indeks dominan adalah 0 - 1 apabila nilai $\mathrm{C}=0$ berarti tidak terdapat jenis yang mendominasi jenis lainnya dan apabila nilai $\mathrm{C}=1$ berarti terdapat jenis yang mendominasi jenis lainnya (Ferianita, 2007). Hasil kedua lokasi tersebut menunjukan tidak terdapat jenis yang mendominasi jenis lainnya, hal ini dikarenakan oleh nilai indeks dominannya adalah 0.115886 0.096733 .
Kriteria indeks keanekaragaman jenis, yaitu jika nilai $\mathrm{H}^{\prime}<1$ berarti keanekaragaman jenis rendah, jika nilai $1<\mathrm{H}^{\prime}<3$ berarti keanekaragaman sedang dan jika nilai $\mathrm{H}^{\prime}>3$ berarti keanekaragaman jenis tinggi (Ferianita, 2007). Berdasarkan hasil tersebut dapat diketahui bahwa pada Sungai Dong Sandar memiliki indeks keanekaragaman sedang dengan nilai (H') sebesar 2.897791 dan pada Sungai Rempangi juga memiliki nilai indeks keanekaragaman jenis sedang yaitu dengan nilai (H') sebesar 2.566213. Indeks keanekaragaman jenis ikan air tawar yang tertinggi terdapat pada Sungai Dong Sandar dengan nilai (H') = 2.897791 yang berarti keanekaragaman jenisnya sedang, serta di Sungai Rempangi memiliki indeks keanekaragaman jenis $\left(\mathrm{H}^{\prime}\right)=2.566213$ yang berarti keanekaragaman jenisnya sedang.

Indeks kemerataan jenis ikan air tawar yang tertinggi terdapat pada Sungai Rempangi dengan nilai $(\mathrm{E})=$ 0.770124 yang menunjukan kemerataan jenis rendah, sedangkan pada Sungai Dong Sandar memiliki nilai $(\mathrm{E})=$ 0.761242 yang berarti kemerataan 
jenisnya rendah. Terdapat perbedaan yang tidak terlalu jauh pada indeks kemerataan jenis antara Sungai Dong Sandar dan Sungai Rempangi. Dapat diketahui kisaran indeks kemerataan jenis adalah $0-1$, jika nilai $\mathrm{E}=0$ berarti kemerataan jenis rendah, dan jika nilai $\mathrm{E}$ $=1$ berarti kemerataan antar jenis relatif merata/sama (Ferianita, 2007).

Berdasarkan perhitungan indeks kekayaan jenis (R) pada kedua sungai, pada Sungai Dong Sandar dengan nilai indeks kekayaan jenis (R) sebesar 7.261776, dan pada Sungai Rempangi memiliki nilai indeks kekayaan jenis (R) sebesar 4.409969, pada kedua sungai ini Tabel 4. Indeks Biologi Ikan Air Tawar di Lokasi Penelitian (Biological Index of Freshwater Fish at the Study Site)

\begin{tabular}{|c|c|c|c|c|c|}
\hline \multirow{2}{*}{ No } & \multirow{2}{*}{ Jenis } & \multicolumn{2}{|c|}{ Sungai Dong Sandar } & \multicolumn{2}{|c|}{ Sungai Rempangi } \\
\hline & & Jumlah & Nilai & Jumlah & Nilai \\
\hline 1 & Anematichthys armatus & & & 10 & 3 \\
\hline 2 & Bagrichthys micranodus & 6 & 1 & 13 & 5 \\
\hline 3 & Barbodes schawanenfeldii & 17 & 4 & & \\
\hline 4 & Chela Maasi & 12 & 3 & 40 & 7 \\
\hline 5 & Cyclocheilichthys apogon & 103 & 10 & 43 & 8 \\
\hline 6 & Hampala macrolepidota & 12 & 3 & & \\
\hline 7 & Helostoma temminckii & & & 40 & 7 \\
\hline 8 & Hemibagrus sp & 6 & 1 & & \\
\hline 9 & Kryptopterus lais & 17 & 4 & & \\
\hline 10 & Kryptopterus palembangensis & & & 8 & 2 \\
\hline 11 & Labiobarbus festivus & 18 & 5 & & \\
\hline 12 & Labiobarbus leptocheilus & & & 8 & 2 \\
\hline 13 & Labiobarbus lineatus & 35 & 8 & & \\
\hline 14 & Macrognathus aculeatus & 11 & 2 & 29 & 6 \\
\hline 15 & Mystus nigriceps & & & & \\
\hline 16 & Mystus wcykii & & & 6 & 1 \\
\hline 17 & Osteochilus kappeni & 49 & 9 & 90 & 9 \\
\hline 18 & Oxygaster anomalura & 23 & 6 & & \\
\hline 19 & Pristolepis grootii & 29 & 7 & 95 & 10 \\
\hline 20 & Pustinus anchispora & & & 12 & 4 \\
\hline 21 & Rasbora tawarensis & & & 13 & 5 \\
\hline \multirow[t]{2}{*}{22} & Rasbora tawarensis & 23 & 6 & & \\
\hline & Total Seluruh Pengambilan Sampel & & 69 & & 72 \\
\hline
\end{tabular}

yang terdapat banyak jenis ikan atau kekayaannya terdapat pada Sungai Dong Sandar.

Berdasarkan perhitungan indeks kesamaan jenis pada Sungai Dong Sandar dan Sungai Rempangi diketahui bahwa nilai (IS) $=57.5 \%$. Nilai indeks kesamaan jenis menunjukan bahwa jumlah jenis pada Sungai Dong Sandar berbeda dengan jumlah jenis di Sungai Rempangi, dapat diketahui bahwa kisaran indeks kesamaan jenis antara 80 - $100 \%$ dianggap sama, $50-80 \%$ dianggap berbeda dan $<50 \%$ dianggap berbeda nyata. 
Nilai setiap jenis per sampel dijumlahkan sehingga memperoleh nilai total dari seluruh pengambilan sampel. Nilai total indeks biologi terbesar terdapat di Sungai Rempangi yaitu 72 dan diikuti Sungai Dong Sandar 69.

Berdasarkan perhitungan biometri diperoleh nilai $b$ hubungan panjang-berat berkisar antara 0-1.5 dari 884 dan nilai b hubungan panjang-tinggi berkisar antara 013 dari 884 individu ikan air tawar. Jika nilai $\mathrm{b}=3$ maka disebut pertumbuhan isometrik artinya pertambahan panjang ikan dengan pertumbuhan beratnya seimbang. Jika nilai $b<1$ atau $b>1$ disebut pertumbuhan allometrik. Jenis ikan air tawar yang berada di Sungai Dong Sandar dan Sungai Rempangi tergolong pertumbuhan allometrik, berarti pertambahan panjang ikan lebih cepat dibandingkan dengan pertambahan beratnya. Sebagaimana dijelaskan oleh Effendie (2002), selama dalam pertumbuhan, setiap pertambahan material ikan akan bertambah panjang di mana perbandingan liniernya akan tetap. Dapat dijelaskan bahwa berat ikan yang ideal sama dengan pangkat 3 dari panjangnya dan berlaku untuk ikan kecil atau besar. Bila terdapat perubahan berat tanpa diikuti perubahan panjang atau sebaliknya, maka kakan menyebabkan perubahan pada nilai perbandingan tersebut.

Nilai indeks keanekaragaman pada kedua sungai tergolong sedang karena posisi kedua sungai saat ini masih terjaga kelangsungan hidup suatu ekosistem di air. Sungai Dong Sandar termasuk kedalam kawasan hutan lindung yang memungkinkan masih terjaganya keaslian hutannya dan jenis-jenis ikan yang masih melimpah belum terjadinya kepunahan. Sungai Rempangi merupakan lingkuhan hutan sekunder dan lingkungan perkebunan kelapa sawit, walaupun jumlah keanekaragamannya masih dikategorikan sedang tetapi ada beberapa spesies yang sudah punah di sungai tersebut karena penurunan kualitas air dan beberapa macam faktor lainnya.

Jenis ikan yang berada pada Sungai Dong Sanadar sangat melimpah itu karena dipengaruhi oleh keadaan lingkungan di sungai tersebut. Sungai Dong Sandar berada di dalam lingkungan kawasan hutan lindung yang merupakan sumber pakan bagi ikan-ikan yang tertentu dan sebagai tempat perkembangbiakan ikan.

\section{KESIMPULAN}

Sebanyak 884 individu yang didapat tergolong dalam 50 jenis dalam 18 famili, 424 individu terdapat di Sungai Dong sandar dan 456 individu terdapat di Sungai Rempangi, satu di antaranya ikan purba yaitu Bagarius yarrelli yang terancam punah keberadaannya. Famili Cyrinidae yang terbanyak dari famili-famili lainnya ada 20 jenis ikan. Indeks keanekaragaman kedua sungai tergolong sedang atau tidak rendah dan tidak tinggi. Keanekaragaman jenis ikan di Sungai Dong Sandar dan Sungai Rempangi Kabupaten Ketapang relatif sedang $\left(\mathrm{H}^{\prime}<3\right)$ dengan indeks keanekaragaamn (H') sebesar 2.94. Hasil indeks keanekaragaman yang tertinggi berada pada Sungai Dong Sandar sebesar 2.89 dan pada Sungai Rempangi sebesar 2.56, memiliki nilai keanekaragaman jenis sedang. Indeks dominan (C) pada Sungai Dong Sandar sebesar 0.09 sedangkan di 
Sungai Rempangi 0.11, yang memiliki jenis yang tidak mendominansi. Indeks kemerataan jenis (E) yang tertinggi terdapat pada Sungai Rempangi sebesar 0.77 dan pada Sungai Dong Sandar 0.76, menunjukan bahwa tingkat kemerataan pada kedua sungai tersebut rendah. Indeks kekayaan jenis (R) Sungai Dong Sandar memiliki jenis ikan yang melimpah dengan nilai 7.26 sedangkan di Sungai Rempangi hanya 4.40. Kemeratan jenis pada kedua Sungai sebesar $57.53 \%$.

\section{SARAN}

Penagkapan ikan yang secara berlebihan dengan cara meracun oleh masyarakat harus dilakukan pengawasan yang lebih intensif, karena dapat merusak ekosistem perairan sungai. Ikan Cyprinidae merupakan ikan yang sangat melimpah di kedua sungai jika dibiarkan dan di racun maka akan terjadi kepunahan juga pada ikan tersebut. Indentifikasi ikan secara melihat buku mungkin bisa terjadi kesalahan, untuk memastikannya spesies harus diteliti lebih lanjut.

\section{DAFTAR PUSTAKA}

Adisoemarto S \& M Rivai. 1992. Keanekaragaman hayati di Indonesia. Kantor Meneg KLH dan Konphalindo, Jakarta,219 hlm.

Affandi R D F Sjafei M F Rahardjo dan Sulistiono. 1992. Fisiologi Ikan Pencernaan. Departemen Pendidikan dan Kebudayaan Direktorat Jendral Pendidikan Tinggi Institut Pertanian Bogor. Hal 215

Budiman A Arief AJ \& Tjakrawidjaya AH. 2002. Peran museum Zoologi dalam penelitian dan konservasi keanekaragaman hayati (ikan). J Iktiologi Indonesia. (2)2: 51-55.

Effendie M I. 1979. Metoda Biologi Perikanan. Yayasan Dewi Sri, Bogor.

Ferianita F M. 2007. Metode Sampling Bioekologi. Bumi Aksara, Jakarta.

Haryono. 2009. Komunitas Ikan di Perairan Bukit Sapathawung Kawasan Pegunungan

Muller Kalimantan Tengah. Jurnal Penelitian Bidang Zoologi, Pusat Penelitian Biologi, Bogor.

Kottelat M A J Whitten S N Kartikasari dan S Wirjoatmodjo. 1993. Freshawater Fishes of Western Indonesia and Sulawesi. Perplus Edition Ltd, Canada.

Mahendra Y Rahayu S E Ibrohim. 2018. Keanekaragaman Ikan Air Tawar di Sepanjang Aliran Sungai Bureng Kecamatan Gendanglegi, Kabupen Malang. Jurnal Biologi, Zoologi, Iktiologi, Malang.

Rachmatika I dan Haryono. 1996. Ikhfauna Taman Nasional Bentung Karimun. Makalah Lokakarya"Keterpaduan antara Konservasi dan Pembangungan kawasan Taman Nasional Bentung Karimun di Perbatasan Kalimantan Barat dan Malaysia”. Pontianak, 13-14 November 1996.

Utomo A D dan Asyari. 1999. Peranan ekosistem hutan rawa air tawar bagi Kelestarian Sumberdaya perikanan di Sungai Kapuas Kalimantan Barat. Jurnal Penelitian Perikanan Indonesia Volume V. No. 3 (1-13). 